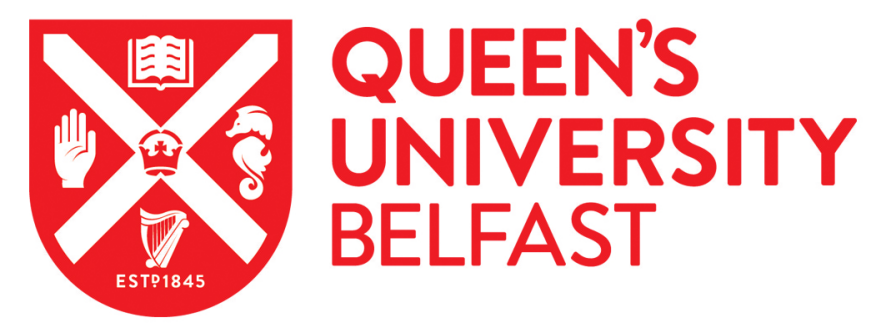

\title{
In the Field with Two Rural Primary School Head Teachers in England
}

Bagley, C., \& Hillyard, S. (2019). In the Field with Two Rural Primary School Head Teachers in England. Journal of Educational Administration and History. https://doi.org/10.1080/00220620.2019.1623763

Published in:

Journal of Educational Administration and History

Document Version:

Peer reviewed version

Queen's University Belfast - Research Portal:

Link to publication record in Queen's University Belfast Research Portal

Publisher rights

Copyright 2019 Taylor and Francis. This work is made available online in accordance with the publisher's policies. Please refer to any applicable terms of use of the publisher.

\section{General rights}

Copyright for the publications made accessible via the Queen's University Belfast Research Portal is retained by the author(s) and / or other copyright owners and it is a condition of accessing these publications that users recognise and abide by the legal requirements associated with these rights.

Take down policy

The Research Portal is Queen's institutional repository that provides access to Queen's research output. Every effort has been made to ensure that content in the Research Portal does not infringe any person's rights, or applicable UK laws. If you discover content in the Research Portal that you believe breaches copyright or violates any law, please contact openaccess@qub.ac.uk. 
In the Field with Two Rural Primary School Head Teachers in England.

\author{
Carl Bagley, Queen's University Belfast, UK
}

Sam Hillyard, Durham University, UK

\begin{abstract}
The research focuses on the complexities associated with contemporary rural primary school leadership. The paper draws on in-depth ethnographic research undertaken in two contrasting English rural primary schools and their surrounding community over a period of three years and in particular the experiences and perspectives of the two head teachers from these schools. The paper is conceptually informed by the work of Bourdieu (1984) and his work around field, habitus and capital as a means of understanding practice. The paper contends that as the neo-liberal economic field increasingly contaminates the field of schooling so a contextual understanding of the complex and shifting social space which a head teacher occupies, including their habitus and the capital they deploy, is of central importance to understanding practice.
\end{abstract}

\title{
Introduction
}

In presenting our work on rural primary school leadership, we wish to closely follow and echo the sentiment of Eacott $(2010,226)$ that there is 'a complex socio-cultural politics to school leadership that is context specific and multi-layered'. Subsequently, in this paper we critically reflect on school leadership practice in two contrasting rural primary schools in England. The aim is to ethnographically uncover and portray the ways in which the head teacher in each school struggles 'to enact a vision of education.... and the relational aspects of this to wider social discourse' (Eacott, 2010, 226). In so doing, we explore in-depth the ways in which the head teachers interpret the multi-layered socio-economic, cultural and political contexts in which their schools are situated and the ways in which their understanding is translated into specific strategies for leadership and community engagement. As Eacott (2010) observes 'leadership is messy and complex and to understand the phenomenon in question there is a need to make explicit the indirectly accessible features of practice'. (Eacott, 2010, 221)

In essence, we contend, research must view leadership theory critically and contextually if the complexities and contestations associated with contemporary rural primary headship are to be understood (Addison, 2009; Eacott, 2010). To-date, while educational research has drawn on the work of Bourdieu, his theories have been relatively under-utilised in relation to educational leadership (Thomson, 2018), even less so in relation to rural school leadership. In this significant regard, the paper sets out to draw theoretically and conceptually on the work of Bourdieu (1984), to analyse rural primary school leadership and to illuminate and articulate the complex and intricate experiences of being a rural head teacher. A school leader, whose situated every day practice, intersects with the social, cultural, political and historical issues beyond the technicalities of managing an organisation'(Eacott, 210, 226). 


\section{English Education Reform}

In England, since the mid-1970s, neo-liberal UK government welfare reforms, including those in education, have witnessed an ever-increasing move towards the marketization and privatisation of services. As a consequence, the types of educational provision, along with its organisation and control and the relationships between those delivering and receiving provision have all changed markedly (Clarke et al. 2000). In policy terms, rural schools and their head teachers, have found themselves responding to reforms that are the product of an English education system conceived and conceptualized largely in urban terms (Corbett, 2016). Moreover, within this neo-liberal urban-centric frame, rural education has tended to be confined or condemned to the policy periphery, discursively devalued and marginalised (Corbett, 2016).

Educational reform - including that in rural areas - has witnessed the ever-diminishing power of local authorities over their governance and funding of specific public services and facilities, with the increasing autonomy of schools. A change evidenced by a policy of local school management, whereby schools control a budget largely determined by pupil numbers and compete for parents to choose their school. At the same time schools are constrained and controlled by a centralised regulatory framework based around standardised notions of inspection, testing, and attainment. As a consequence, head teachers, often with diminishing resources, find themselves in a highly competitive environment, charged with improving school performance. Against this backdrop and under the auspices of what has been termed New Public Management (NPM), the role of head teacher as school leader, along with the act of managing and management, has been discursively reformulated, recalibrated, and repositioned (Gunter et al 2016). Gunter et al $(2016,22)$, speak of a process of continual multi-layering of educational reform over the last thirty years, resulting in a system which 'can be characterized as one of complexity, even chaos'. Ball (2009), describes the new forms of emergent educational governance associated with these changes as 'heterarchies' constituted as 'a new mix of hierarchy, market and network which is replete with overlap, multiplicity, mixed ascendancy, and/or divergent but co-existent patterns of relations' (Ball, 2009, 100). These 'heterarchies' serviced and managed by new kinds of policy actors, including head teachers, situated in differing nodal positions of influence and power (Ball, 2009).

In reflecting on the work of Ball (2009), Woods and Simkins (2014) consider the ways in which at the local level such new forms of governance in the shape of national and school networks, school federations and collaborations are creating not only challenges but establishing new opportunities for head teachers. In such an evolving policy environment they observe:

There are pressures towards the development of local actors as entrepreneurial players and the growth of the 'enterprising self' (Smyth, 2011) since the local in the emerging system involves calculation, opportunity-spotting, sometimes risk-taking, and acting purposively in uncertainty to construct innovative and untested ways of working within and between institutions.

(Woods and Simkins, 2014, p. 335) 
Woods and Simkins (2014) importantly stress that the behaviour and actions of head teachers cannot automatically be assumed to be individually and competitively motivated and orientated. They contend that the psychological and socio-cultural positioning of head teachers within this changing policy environment is complex and nuanced, based amongst other things on self-identity and aspiration and the strategic decisions they chose and strive to make as policy actors within a specific local context (Bottery et al. 2007, 2008). In understanding the challenges for rural school head teachers, so an appreciation of this local context is key (Wong, 2011). We would contend however that these challenges, whilst localised and complex, cannot be removed from the broader socio-economic, political and structural discourses outside of education, in which rural schools are situated, framed and required to respond. In this sense, the local context is undeniably important in understanding the experiences and decision-making of rural school head teachers. But the issues encountered are arguably not so much unique as intensified and amplified. For example, while all English schools find themselves in a competitive environment, fixated on securing viable student numbers, so in less populated rural areas the situation faced by head teachers is potentially so much more acute.

In an attempt to qualitatively understand the predicament of the two rural primary head teachers in our study we turn theoretically and analytically to the work of the French Sociologist Pierre Bourdieu (1984).

\section{Engaging Bourdieu}

In engaging a Bourdieusian analysis to an understanding of rural primary school leadership we are striving to move away from a normative reading of leadership, to one which acknowledges it's temporal, complex and situated nature. In this way, we are placing the individual actor in local context whilst appreciating the simultaneous interplay of both micro and macro level forces in shaping practice (Eacott, 2010). The notion of practice we use in this study is theoretically informed by the work of the French Sociologist Pierre Bourdieu, who in his text, Distinctions, (Bourdieu, 1984, 101) presents the following equation to explain his conceptualisation: [(habitus) (capital)] + field $=$ practice. Practice is thus determined by the habitus of actors, the capital they possess and the ways in which they participate in a particular field. In this paper the concepts of habitus, capital and field are adopted as a theoretical means of examining the social spaces encountered and occupied by the head teacher and the ways in which they assess and respond to these social spaces in their professional lives or practice (Lingard \& Christie, 2003). While Bourdieu's (1984) social theory of practice highlights the interrelationship between the concepts of habitus capital and field, for heuristic purposes we consider each of these concepts in turn.

\section{Habitus}

Bourdieu's (1977) concept of habitus is used methodologically to address the dualisms of agency-structure; the concept used to signify that 'not only is the body in the social world but... the social world is in the body' (Reay, 2004, 432). Habitus is thus neither wholly the result of free agency nor determined simply by structures. It a consequence of the interplay between agency and structure created through long standing ephemeral social process which can unexpectantly fluctuate and change (Navarro 2006). Bourdieu (2000) subsequently provides a definition of habitus that situates the concept against both structural constraint and individual agency. 
He states:

I developed the concept of 'habitus' to incorporate the objective structures of society and the subjective role of agents within it. The habitus is a set of dispositions, reflexes and forms of behaviour people acquire through acting in society. It reflects the different positions people have in society, for example, whether they are brought up in a middle-class environment or in a working-class suburb. It is part of how society produces itself.

(Bourdieu, 2000, 19)

While in terms of habitus an individual is equipped with agency, individuals are likely to lean towards or be (pre)disposed to particular ways of behaving, inextricably bound up with cultural/structural changes (Reay, 2004). Habitus influences the relationship individuals have with 'localised issues of history and geography'. (Reay, 1996, 581). It creates a 'sense of one's place', an understanding and awareness of those things' individuals consider as something with which they should become involved or wish to exclude (Swartz, 1997, 106). In this regard habitus is specific to each individual, it is 'the way society becomes deposited in persons in the form of lasting dispositions, or trained capacities and structured propensities to think, feel and act in determinant ways, which then guide them' (Wacquant 2005, 316). As Lingard et al $(2000,36)$ observe, 'Habitus is the sedimentation of history, structure and culture in individual dispositions to practice'; one directly influenced by the capital they possess.

\section{Capital}

Capital is a key resource informing habitus, with particular forms defining positions and possibilities of the various agents in any field. Bourdieu (1986), identifies the four forms of capital as economic capital (wealth or money), cultural capital (the ability to navigate the systems of knowledge deemed valid by a society), social capital (networks of relations), and symbolic capital (marks of prestige and honour). For Bourdieu (1986), capital is concerned with an agent or individual's position within an inequitable class-based social structure; the dominant class defining who possesses the most property and wealth, what counts as legitimate knowledge, which social relations are valuable and what symbols confer prestige and social honour within any given field.

\section{Field}

We are taking field to be those social and institutional arenas constituted by networks, structures or relations at micro and macro level, which 'produce and authorise certain discourses and activities' (Webb, 2002, 21-22). According to Bourdieu (1992) a field is:

... a structural social space, a field of forces, a force field. It contains people who dominate and people who are dominated. Constant, permanent relationships of inequality operate inside this space, which at the same time becomes a space in which the various actors struggle for the transformation or preservation of the field.

(Bourdieu, 1992, 40-41). 
For Bourdieu (1996) there are numerous different fields including the economic, the literary, the scientific as well as the educational, each with their own boundaries, differentially constituted with its own agents, relationships and structures (Lingard and Christie, 2003). In line with what we have already alluded to in the introduction to this paper, Bourdieu (1996) identifies the boundaries around the field of education as increasingly breached by the field of the economy, as discourses around marketization and managerialism come to dominate (Addison, 2009). Moreover, each field operates as a complex, changing, participatory social space; 'historical constellations that arise, grow, change shape, and sometimes wane or perish, over time' (Wacquant, 2007, 268). Consequently, a field is not fixed, but is temporal, under constant production and reproduction (Thompson, 1999). Theoretically, field and habitus are interrelated:

On one side, it is a relation of conditioning: the field structures the habitus...... On the other side, it is a relation of knowledge or cognitive construction: habitus contributes to constituting the field as a meaningful world, a world endowed with sense and with value, in which it is worth investing one's energy

(Bourdieu, 1992, 44)

The interaction between field and habitus is both predictable and unpredictable and as a consequence the implication for the practice 'is dynamic, fluid and a product of the dominant fields in play at any given time' (Addison, 2009, 334). Habitus thus has a major influence on the ways in which individuals respond to situations and on their understanding and practices temporally shaped and reshaped by the impact of various fields.

\section{The Ethnographic Study}

As Bourdieu (1993, 271) observes, 'One cannot grasp the most profound logic of the social world unless one becomes immersed in the specificity of an empirical reality'. In line with this contention, the data featured in this paper is derived from a three-year UK Economic Social Research Council (ESRC) funded ethnographic project, undertaken in two contrasting English village communities, Cowshill ${ }^{1}$ in the South and Minbury in the North East. The aim of the overall study was to explore in-depth rural life and education in the twenty-first century and in particular the interrelationships between the local village school and its community. The focus of this paper, on the head teachers in the two locales, is derived from a sub-set of data from the larger investigation.

In terms of the ethnographic settings, Cowshill had historically been dominated by agriculture and the farming industry and increasingly tourism in recent decades. Minbury, like many of the region, had been a 'pit village' dominated by coal-mining, but with the ending of the UK coalmining industry had economically sought to re-orientate toward service/ State sector employment. Both villages had experienced a social history of economic decline and their centres were neither the employment nor social hubs they had once been.

Minbury's was the larger of the two primary schools with a roll of around 150, reflecting the village's larger population (circa, 2000). Cowshill with a population of around 600 had a much smaller school roll with approximately 50 children attending the school. The regional cluster of schools within which each primary was based meant that both encountered intense

\footnotetext{
${ }^{1}$ Both village names are pseudonyms.
} 
competition from other schools in terms of retaining their pupil numbers based on parental choice. The Minbury school had recently relocated to a new-build on the periphery of the village, which the head teacher had painted red 'to ensure everybody knew we are still here'. In contrast, Cowshill primary had remained in its Victorian location at the very centre of the village, however as other amenities within the village had declined (it now only had one shop), so footfall around the oldest part of the village had declined markedly and whilst geographically central the school had lost its central social and cultural position in the life of the village. The ethnographic study employed participant observation inside the village schools and the village, semi-structured interviews (circa 29 in each setting), with key groups including school staff, parents, the governing bodies and members of the local community. Fieldwork also included 'in-the-field' interviews (circa 40 in each setting) with village residents individually and collectively (long standing and new arrivals) in a host of informal settings including social clubs, public houses, community centres, shops and personal homes. A detailed use was also made of documentary material including school inspection reports, ordnance survey maps, residents' websites, parish newsletters and social history records and accounts relating to each village.

A pivotal gatekeeper and informant in each setting was the school head teacher, with whom rapport and sustained contact was importantly maintained throughout the whole course of the three-year field work period. This period of prolonged engagement facilitated a sense trust and openness between ourselves and the head teachers, providing access not only to all aspects of the local schools, but insightful personal and professional perspectives on their role. Subsequently, in addition to numerous informal conversations, we conducted around 8 one-hour in-depth semi-structured interviews with each head teacher. It is primarily from those interviews from which the findings presented in this paper arise. In deciding to present those findings primarily in the form of interview data we do not hold with the position which contends that an over reliance on data of this kind does not constitute the ethnographic. On the contrary, and aside from the prolonged periods of immersed fieldwork which made the capture of this rich data possible, we believe what is 'essential to ethnography is a concern with capturing participant perspectives' (Hammersley, 2006, 3). Our interviews enabling the rich ethnographic capture, interpretation and positioning of what is said in relation to biography and context.

An inductive approach was adopted, with data analysed thematically through the generation of initial codes, identification of specific themes, thematic review and report production (Braun and Clarke 2006). In the next section we identify and discuss the main findings from the inductive analysis. In so doing the section seeks to compare and contrast the experiences and perspectives of the rural primary school head teachers and the ways in which they may be understood in relation to Bourdieu's (1994) conceptualisation of practice.

\section{Research Findings}

Observation of the social world of the head teacher at both rural schools revealed the somewhat chaotic and complex professional role they encountered and undertook in the field of education. As the Cowshill head teacher with frustration outlined: 
Working on the school development plan, or [...] those big things that you can't just keep dipping in and out of while the phone's ringing or while you're giving a child a sticker, or talking to a member of staff who's got a crisis, or a parent who's comes in about performance, or a rep who's wandered through the door with something you would quite like to buy if you had the money. You're in charge of special needs and literacy and the budget and risk, health and safety and there aren't enough hours in the day to do all those things.

(Cowshill, head teacher)

For the Cowshill head teacher the problems associated with leadership were exacerbated by the small size of the rural school where, as he observed, "everybody wears 27 hats". Similarly, the head teacher at Minbury reported on the ways in which she "juggled" with a myriad of issues and concerns that were pastoral, educational and political and which involved students, parents and local bureaucrats. As she stated, with a degree of exasperation:

One minute you have a child who has fallen over in the playground and crying, at the same time as the phone rings and the local authority want to know about admissions and a parent in the corridor wanting to speak about her son's performance......and decisions need to be made and documents signed, letters to go out and this is all happening at once. It's definitely getting worse than it was when I first came into teaching. I mean we can manage but I know for my colleagues in much smaller rural schools with fewer staff find it can be particularly tough.

(Minbury head teacher)

The above statements reveal the ways in which each head teacher not only experienced a host of diverse professional pressures but also the ways in which their ability to deal these pressures was in part potentially exacerbated by the relatively small number of staff members in the school. As well as encapsulating the professional complexity and 'messiness' of their roles, the comments by the two head teachers allude to the ways in which the field of schooling is changing and 'weakening' in terms of its boundaries. Consequently, we see references to responses to budgetary concerns associated with local management, requests from the local authority concerning pupil numbers and from parents on academic performance. As Addison (2009) observes:

Principals have not operated in an educational vacuum for many years, even given the familiar architecture of their schools. The contemporary organisational space confronting school principals is dominated by a layered interaction of a number of competing fields, most notably the all-encompassing demands of the economic field. The impact of domination by the field of schools by the field of the economy has made the principal leadership of schools complex, layered and increasingly uncertain

(Addison, 2009, 331)

Addison (2009) contends it is in understanding the ways in which school principals deal with multiple pressures from different fields which is at the heart of present-day school leadership. Certainly, in our study we found that whilst the head teachers sought to deal with a range of educational issues related to pedagogy and the curriculum, the discursive presence of marketization, performativity and managerialist issues of the kind referred to earlier in 
relation to new public management (Gunter et al. 2016) were found to be ever present and professionally pervasive; an encroachment over time which brought with it specific and heightened concerns for the rural primary school. As the Minbury head teacher with a hint of nostalgia reflected:

Since I came in to teaching 20 years ago, the last 5 here as head teacher, I have seen an ever-increasing pressure placed upon teachers and teaching, it is about performance how well we perform in standardised tests, where we finish in the league tables and as well as Ofsted and the unbelievable stress and pressure inspection places on everyone. But even though my educational priorities might be elsewhere we have to comply and I would be lying if I said we didn't want to do well and who doesn't want to be graded excellent.... and of course we have parents being able to choose their school which means school competition and in rural areas numbers are small and you are always conscious of the threat of closure

(Minbury, head teacher)

The above statement testifies to the way in which the field of education, as experienced by the Minbury head teacher, is not fixed, but rather temporal and dynamic (Thompson, 1999), with the ever encroachment of new public management. As Addison $(2009,335)$ observed so much of a school principal's time is now given over to issues as 'risk management, governance and enterprise bargaining'. As a consequence, the role the head teacher is a much about seemingly corporate business-related matters as it is about those one might have previously deemed educational. Moreover, as the Minbury head teacher stipulates, they have very little option in relation to school inspection, school choice and performance-based league tables other than to comply with the dominant performative managerialist rationale of the neo-liberal economic-informed and educational fields in play. For both head teachers, the professional environment in which they were expected to lead and manage their schools was one in which they were under consistent pressure to perform well against externally imposed government targets. As head teachers of rural schools operating in a performative driven culture of inter-school competition and school choice, emanating from the economic field of new public management, with survival based on pupil numbers, the threat of school closure was ever present. In Bourdieusian terms, as the boundaries of the educational field became increasingly permeated by the field of the economy, so it informed the habitus and shaped the practice of the head teachers in our study.

For the head teacher of the much smaller rural school in Cowshill, the possibility and resultant managerial pressures of school closure resulting from competition and school choice were particularly acute. As the head teacher pessimistically observed:

I don't think it [the school] will survive, because I think you'll keep creaming off the top, all the time. And standards this year are dreadful...they're a particularly poor year going through but, increasingly, we are getting the bottom end of the market and that's going to make life really hard for us to survive. You've got an area in which the wealthy people, their children don't come here. When I arrived there, the first thing I did was went and had a drive round the school catchment area.

(Cowshill head teacher) 
The above quote signifies the way in which on his appointment the Cowshill head teacher applied his cultural capital in seeking to understand the competitive position of the school in terms of its intake. His appreciation of the field informed his understanding that due to school choice, the school over a number of years had seen it's pupil profile change markedly. In effect, more affluent middle-class parents with access to private transport had, in deploying their economic, cultural and social capital, chosen not to send their child to the school. As a consequence, at the time of the fieldwork the school numbers were falling and the academic profile according to standard attainment tests suggested pupils underperforming in the school. Furthermore, the situation concerning pupil numbers was compounded due to a marked shift in the demographic within the village, which included those coming into the village at the point of retirement ie families with no school age children, requiring Cowshill to look even harder beyond its immediate vicinity for its intake. Hence, at the time of the fieldwork, school numbers were falling, half of the school roll was from outside the village and as the head teacher stated the school faced a very real threat of closure.

In Minbury, the school had also experienced and impacted by the pressures of competition and choice in their rural area (see Bagley and Hillyard, 2015). The changing demographic in Minbury meant the school was attended entirely by long standing working-class residents; middle class newcomers to the village found to have much less loyalty towards attending the school. In a similar manner to that experienced in Cowshill, more affluent newcomer parents had deployed their forms of capital to choose a different primary school in another village; a choice made not on the grounds of proximity and locale but the perceived academic advantage attendance at such a school might afford their child (Bagley and Hillyard, 2015).

Interestingly, we found the deployment of capital by the headteachers and their habitus towards the performative and competitive pressures in the field of education they encountered were quite similar. Both remained committed to strong educational values associated with local community engagement as the best mechanism by which to ensure their school's survival in a competitive environment. This shared professional commitment to engendering strong school-community relations had become heightened following their move to a school in a more rural setting. In essence, each head teacher appreciated the ways the local primary school could and should play a significant role both material and symbolic in the life of the village (see Bagley and Hillyard, 2012). This understanding of the school's temporal and spatial significance made them both professionally determined to establish a rural primary school that was an integral part of the local village community, one open to parents and one which they felt comfortable visiting, and hopefully choosing. In this sense their commitment to establishing the rural school at the 'heart of the community' (Bagley and Hillyard, 2010) spoke to their professional values as well as been seen strategically as an approach to engender school choice and keep their schools open.As each of the head teachers remarked:

I think rural primaries should be encouraged to be as much part of the local community as they can possibly be. And I think so many schools now take such an introverted view because they are so concerned about the next inspection or the next set of results, and that sort of thing.

(Cowshill head teacher)

As we get more school inspection, more boxes which have to be ticked, more worries that your school isn't performing as well as the school down the road and you fear 
parents might start to choose it instead of you, even though you know you are doing a bloody good job in difficult circumstances, it all adds to the stress and pressure and you have to find ways of coping of not getting distracted from what you think is right, while all the while making sure those boxes are ticked. I consider myself to have a strong understanding of what needs to be done in order for this school to survive. Yes, number one I want it to be part of the community and for families to feel welcome and see this as their local school but of course I think that in trying to create that I hope it will mean them wanting to choose this school for their children

\section{(Minbury head teacher)}

The commitment to engender strong school-community relationships was thus for both head teachers not simply in terms of school choice but the broader educational value and benefit they believed resulted from stronger parental involvement in the schooling of children (Henderson \& Mapp, 2002, Ho \& Willms, 1996). Preston and Barnes (2017), in their review of the rural leadership literature (published between 2005-20015), in American, Canadian, and Australian settings, found the key factor for successful leadership, regardless of the school's location, staff, number, type, or academic level of students, to be collaboration.

Significantly however, while the head teachers held a similar habitus towards engendering strong school-community relations, the local field of education they encountered varied markedly between Minbury and Cowshill. A situation which impacted differentially on the ability of the two head teachers in practice to establish positive working relationships with parents and the local community.

In Cowshill the head teacher recognized and acknowledged that it was going to be 'jolly hard work', to build and sustain a local community commitment to the school. In speaking to the 'historical constellations' of the field (Wacquant, 2007, 268), the Cowshill head teacher (in marked contrast to the situation in Minbury) had inherited a school whose relationship with the local community had deteriorated over time. As such a level of mistrust had developed, with the school under previous head teachers materially and culturally 'cutting itself off' from the community it served. As the current head teacher observed:

I believe previously the school wasn't perceived to be a school that was open to the community. when they had things like assemblies and the parents were invited in, the rest of the school was locked so that people couldn't stray! Don't go and wander into classrooms or see what was happening, or anything like that. So, a lot of the problems with the parents are that they had bad experiences at school. [...] I had one woman who came and really railed at me because I hadn't sent a message home to say that her son had been to see me. And what had he done wrong? Well, didn't he show you the sticker he got because he'd done a lovely piece of work? But because he'd gone home and said he'd had to go and see the head teacher, she thought that he'd done something wrong $[. .$.$] you still hear them saying - it drives me mad - oh you don't$ want to go and see the Head Teacher. Actually, no, I do want them to.

(Cowshill head teacher)

Historically, the inability of Cowshill to recruit and 'keep' a head teacher for a prolonged period of time had arguably contributed to the lack of any consistency and continuity of 
school leadership. As a result, over the last 20 years there had been a total of 22 heads, 11 of which had been acting rather than permanent.

There has been too much change, so they can't trust anything anymore. What am I? I'm the third Head in four terms. And we all come in and we're all doing the same job, but we all do it differently. We all have different ways we want to do it and different ways that probably we engage with the parents and, like children, they just find it confusing.

(Cowshill, head teacher)

As the above quote suggests, each new head teacher potentially entering the field with a different habitus and stores of capital, and thus holding to different views on school leadership and community engagement. Or indeed a different value position towards new public management and schooling. In its effect the high turnover of head teachers at Cowshill had resulted in a fragmented relationship existing between the school and the local community, one which the current head teacher desired to confront and change:

We need to get them in, show them [...] actually what we do is quite good'. they just haven't got trust in us. I think there's a lot of that. Yeah. I think it's the only way forward, actually to become a proper community school. [.... ] I just would want the community here more $[. .$.$] so that the parents are really engaging in the school.$

(Cowshill, head teacher)

At the time of the field work the habitus and cultural capital of the Cowshill head teacher had enabled an appreciation and perception of what needed to be undertaken strategically within the field of schooling for the survival of the school; a position similar to the one held by the head teacher in Minbury. As stated previously however the local field of education in Minbury was markedly different.

The Minbury school had not experienced a high turnover of school leadership, had a wellattended and active parent-teacher association and operated an open-door policy providing a regular opportunity for parents to see their child's class in action. Parents were able and desired to use the school (unlike the situation in Cowshill), to meet and chat with other parents, and to this end the school had recently opened designated room which parents used as a social drop-in for coffee and biscuits. As the head teacher passionately observed

The school is one of the few constants in local people's lives and it was important for me to help make sure we keep it for the sake of the village and use it in a way that was more than simply making sure we performed well in Ofsted, it was about giving the kids a better start in life, I suppose a chance to get out and away from the kinds of everyday poverty we have around here. I was lucky in that I inherited a school which was already seen as part of the community, my job was to build on that which I think over the last few years I have done

(Minbury head teacher)

In highlighting the differing local fields of education 'inherited' by the two head teachers 
the research reveals the ways in which their professional practice, while informed by a similar value perspective towards strengthen school-community relationship for the educational benefit of the pupils and school survival, arguably requires a differential deployment of capital to achieve their goals. The local field of education in Cowshill making the task for head teacher considerably more difficult to achieve. Nevertheless, both head teachers were found to have a strong professional understanding of the external economic field pressure, their local field and as the Cowshill head teacher stated 'what the problems were and what needed to be done'. As the Minbury head teacher with a degree of selfconfidence, similarly remarked:

The thing is I know what I want to achieve regards the school and the community and I have a fairly clear idea of how I am going to achieve it, what needs to be done, who needs to be seen, which local councillor I need to get on board and which parents are the activists and have the strongest local voice. I have been at this for quite a while now and you get to know intuitively what is the right thing to do...

(Minbury head teacher)

This final quote, from the Minbury head teacher, referring to her understanding of the field, a habitus in support of fostering strong school-community relations and the deployment of capital to engage the network of stakeholders to achieve her goals, captures nicely, from a Bourdieusian perspective, the ways in which rural school leadership practice needs to be taken and conceptualised holistically as [(habitus) (capital)] + field = practice (Bourdieu, 1984, $101)$; each category only fully formed and understood when taken in relation to the other (Eacott, 2013).

\section{Discussion and Conclusion}

In presenting our ethnographic analysis, we would contend that Bourdieu's conceptualisation of practice, formulated in terms habitus, capital and field, provides a valuable theoretical lens through which to understand 'the contextual constraints and individual possibilities' (Lingard and Christie, 2003, 319) in the work of head teachers. As Thomson (2001) states

Bourdieu ... makes it possible to explain how the actions of principals are always contextual, since their interests vary with issue, location, time, school mix, composition of staff and so on. This 'identity' perspective points at a different kind of research about principal practice: to understand the game and its logic requires an analysis of the situated everyday rather than abstractions that claim truth in all instances and places.

(Thomson 2001a, 14)

We consider the application of Bourdieu's social theory of practice to school leadership advances analytical understanding of the inter-relationship and inter-dependency between agency and structure in social context. In particular, the research reveals how the field of education has come -certainly in our two case study areas - to be dominated and structured by neo-liberal new public management discourses. These discourses are conceived in the economic field, and subsequently inform and shape the practices of schools and school leadership (Gunter et al. 2016). We believe the application of Bourdieu's (1984) notion of 
field(s) to offer an important theoretical lens through which to uncover and understand the practice of head teachers, including those in rural settings. As Addison $(2009,333)$ observes the economic field 'has transformed the workspaces of principal practitioners almost beyond recognition' with school leaders, such as the head teachers in our study, required to deal with the implications on a daily basis. Lingard and Christie (2003, 326), in similarly acknowledging the influence and impact of the economic and political fields on education, locate school principals 'at a point between the policy producing apparatus and the practices of schooling'. They elucidate that head teachers, in finding themselves located at the apex of differing fields, have to 'negotiate various logics of practice' (327) not least in relation to the dominant 'logic' of 'new managerialism and the culture of performativity' (p.327). These field pressures discursively positioning head teachers as managers of schools rather than school leaders (Lingard and Christie, 2003).

The notion of rural head teacher practice which emerges from our study is one which is complex, temporal, liquid and relational to the dominant fields encountered. As the scope of our investigation is limited to only two contrasting rural sites it is not possible to determine the extent to which the experiences of our two head teachers are generalisable. Nor is it possible to ascertain the extent to which there is something distinctive about their experiences as rural primary school head teachers compared with those in urban settings. Although Certainly, the pervasiveness of new public management and neo-liberal reform has influenced and impacted education policy development across all aspects and sectors of the English Education system (Gunter, 2016). What our study is capable of revealing is the extent to which, in these two specific rural settings, the pressures permeating from the economic field in terms of performativity, competition and choice are exacerbated and intensified The result of a situation in which rural school student numbers are low and the concomitant possibility of school closure a real threat.

We would tentatively contend that both head teachers in needing to deal professionally with diverse cross paths of multiple fields, including the vagaries of a particular local education field, have in part developed what Bourdieu, $(1990,11)$ calls a 'feel for the game'.

Action guided by a 'feel for the game' has all the appearances of the rational action that an impartial observer, endowed with all the necessary information and capable of mastering it rationally, would deduce. And yet it is not based on reason. You need only to think of the impulsive decision made by the tennis player who runs up to the net, to understand that it has nothing in common with the learned construction that the coach, after analysis, draws up in order to explain it and deduce communicable lessons from it.

(Bourdieu, 1990, 11)

This 'feel for the game' is perhaps more evident in the findings from the Minbury study where the head teacher explicitly states, following years of immersion in the field, how she is at times able to respond 'intuitively' to the complex array of multiple demands on her time and services as fields cross and collide. Even so, the habitus of each head teacher has arguably provided them with a tacit, 'embodied... second nature' strategic appreciation (Lingard and Christie, 2003, 325), of when and how to deploy appropriate levels of capital in response to predicaments encountered within their field of education. As Lingard and Christie (2003) observe: 
Strategy entails 'moves in the game' which are based on mastery of its logic, acquired by experience, part of the habitus.. This allows for actions guided by constraints, as well as for improvization, different levels of skill, and choices to be made in particular situations.

(Lingard and Christie, 2003, 325)

Interestingly, as we have revealed, the pressures from certain fields such as the economic are ones which the head teachers in the study appear to accept as professionally and administratively inevitable. Nonetheless, their habitus and store of capital is such that they professionally seemingly chose not to simply acquiesce to the values associated with these pressures. Rather they seek to absorb and accommodate these values within their habitus. As Thomson (1999) observes:

Becoming a school principal according to Bourdieu is then a slow and lengthy process of acquiring not only the symbolic and cultural capitals necessary for participation in the field, but also the processes of investing in the game, accepting its doxa and its ways of being, learning the strategies of participation, and acquiring the habitus, that embodied sense of being an administrator.

(Thomson, 1999 http://www.aare.edu.au/data/publications/1999/tho99060.pdf)

Arguably, for both head teachers in our study, while they understand the rules of the game or dominant doxa of the field, their educational standpoints might be interpreted as not simply being concerned with making sure they play the existing 'game better, but possibly challenging the very nature of the game and the formula for success' (Eacott, 2013, 175). The head teachers, holding to a value position, around engendering strong collaborative school-community relations, constituting a discursive (re)positioning in relation to the economic field, which could be conceived as potentially disruptive. In a similar finding, Devine (2013), in her work on school leadership in relation to multi-ethnic schools, applies a Bourdieusian analysis to reflect on practice and the tensions in the field concerning not simply its preservation but also possibilities for its transformation. For Bourdieu, according to Eacott (2013), social transformation in the main occurs according to:

.... a theory of crisis or hysteresis where the habitus falls out of alignment with the field in which it operates, creating a situation in which belief in the game (illusio) is temporarily suspended and the orthodoxy of practice or doxic assumptions are raised to the level of discourse, where they can be contested

(Eacott, 2013, 175).

Eacott (2013) contends that disruption to the game should not simply be limited to moments of crisis. Rather he suggests a conceptual shift in thinking akin to Bourdieu's (2005) classification of a firm as a field in its own right, whereby one conceptualises the individual school not as a subfield within the field of education but as a field in its own right. Devine (2013) adopts a similar position in arguing that the field can be constituted by the school itself. Schools are thus positioned as 'structured social spaces with their own 'logics' of practice-configurations of power and representation that have developed over time' (Devine, 2013, 394)

Such a reconceptualization, enables an analytical approach capable of engaging the complex black box workings of the school as a structure with relative autonomy' (Eacott, 2013, 179). The 
emphasis here placed on the importance of acknowledging the relative autonomy of the field rather than other structural limitations placed upon it.

In this way key players within a school such as the head teacher are able to develop a social disposition or habitus shaped through biography 'affected by their field location as well as through relations with time and space'(Eacott, 2013, 179). A habitus, so constituted, importantly having the 'the skills required to deconstruct and actively challenge the orthodoxy, or doxa of education' (Eacott, 2013, 179). Such a process being akin to what Bourdieu $(1990,116)$ describes as 'socioanalysis' whereby individuals within a field are able to become reflexively and critically aware of the structures which inhibit or shape their practice. positioning, depending on their access to capitals, from which individuals are able to either preserve or subvert the field (Bourdieu and Wacquant 1992).

The important point to be made here relates to the intellectual spaces for critical reflection and practice which exist for school leaders like those in our study. Arguably, such head teachers, when positioned in the relatively autonomous field of the school, are able to challenge the dominant economically infused doxa of education and to prioritise community engagement and collaboration at a time of individualism and competition. As such the agency of head teachers should not automatically or simply be assumed to be individualistic and competitively driven (Woods and Simkins, 2014). On the contrary head teachers are able to reflect on the position they wish to adopt within a given field. As policy actors, they are able to make informed decisions as to their professional identity and agency and the strategic decisions they wish to prioritise and take within a specific local context (Woods and Simkins, 2014) or in relation to other fields.

The form of habitus and its lasting dispositions, are specific to each individual (Wacquant 2005) and thus individual head teacher in differing rural primary school may well exhibit a completely different disposition towards practice. It was coincidental that in our study head teacher dispositions were found to be broadly aligned, to enhancing community engagement. Even so, the research reveals . the nuanced and variegated characteristics of rural schooling, and the different demands upon head teachers, depending upon which field of schooling they find themselves and the implications of this local context for practice. in drawing on the work of Bourdieu (1984) and applying his conceptualisation of practice to our two case study areas we hope to have tentatively signalled an approach capable of engaging critically and contextually with the nuanced complexities of rural primary school leadership. In so doing we have sought to move away from an a-historical decontextualized account of school leadership to one which is more strongly theorised, problematized and empirically ethnographically grounded.

\section{References}

Addison, B. (2009). A feel for the game - a Bourdieuian analysis of principal leadership: a study of Queensland secondary school principals. Journal of Educational Administration and History, 41(4), 327-341

Bagley, C., \& Hillyard. S. (2011).Village Schools in England: At the heart of their community? Australian Journal of Education 55(1), 5-12

Bagley, C. \& Hillyard, S. (2014). Rural schools, social capital and the Big Society: a theoretical and empirical exposition. British Educational Research Journal 40 (1), 63-67. 
Bagley, C \& Hillyard, S (2015). School Choice in an English Village: Living, Loyalty and Leaving. Ethnography and Education 10 (3), 278-292.

Bottery, M., G. Ngai, P.M. Wong, and P.H. Wong. 2007. Different context, different problems? Comparing the views of English headteachers and Hong Kong principals. Management in Education 21, no. 4: 14-18.

Bottery, M., G. Ngai, P.M. Wong, and P.H. Wong. 2008. Portraits of resilience: Headteachers in two different cultures. Education 3-13 36, no. 2: 183-99.

Bell, M. M. (2007). The two-ness of rural life and the ends of rural scholarship. Journal of Rural Studies, 23, 402-441.

Bell, A. \& Sigsworth, A. (1987). The heart of the community: Rural primary schools and community

Development. Norwich: Mousehold Press).

Bourdieu, P. (1977). Outline of a Theory of Practice. Cambridge: Cambridge University Press.

Bourdieu, P. (1984). Distinction: A Social Critique of the Judgement of Taste. London: Routledge and Kegan Paul.

Bourdieu, P. (1986) The forms of capital. In J. G. Richardson (Ed.) Handbook of theory and research

for the sociology of education (pp. 241-258) New York, NY: Greenwood Press

Bourdieu, P (1990) In Other Words: Essays toward a Reflective Sociology, Stanford

Bourdieu, P. (1992). Towards a Reflexive Sociology: A Workshop with Pierre Bourdieu, Sociological Theory 7(1) 44.

Bourdieu, P. (1996). Rules of Art: Genesis and Structure of the Literary Field. Stanford, CA: Stanford University Press, 1996.

Bourdieu, P. (2000). The politics of protest. An interview by Kevin Ovenden. Socialist Review 242, 18-20.

Bourdieu, P., \& Wacquant., L. J. D. (1992). An Invitation to Reflexive Sociology. Chicago, IL: University of Chicago Press.

Braun. V., \& Clarke, V. (2006) Using thematic analysis in psychology. Qualitative Research in Psychology 3(2), 77-101.

Church of England (2014). Working Together.The Future of Rural Church of England Schools. London: The Church of England's National Education Office

Clarke, J., Cochrane, A,. \& Mclaughlin, E. (2000). Reinventing the Welfare State. In J. Clarke, S. Gewirtz,\& E Mclaughlin, (Eds.), New Managerialisn New Welfare (pp 1-26). London: Sage 
Corbett, M. (2016). Rural futures: Development, aspirations, mobilities, place and education. Peabody Journal of Education, 91(2), 270-282.

Devine, D (2013) Practising leadership in newly multi-ethnic schools: tensions in the field?, British Journal of Sociology of Education

Eacott S. (2010) Studying school leadership practice: A methodological discussion Issues in Educational Research, 20(3), 220-233

Eacott, S. (2013). Towards a theory of school leadership practice: A Bourdieusian perspective. Journal of Educational Administration and History, 45(2), 174-188.

Gunter, H. J. (2000). Thinking theory: The field of education management in England and Wales.

British Journal of Sociology of Education, 21(4), 622-635.

Hall, D., \& Gunter, H. M. (2016). Permanent instability in the European educational NPM 'laborartory'. In H. M. Gunter, E. Grimaldi, D. Hall, \& R. Serpieri, (Eds.), New Public Management and the Reform of Education (pp21-35). London: Routledge.

Hammersley, M (2006) Ethnography: problems and prospects, Ethnography and Education, 1 (1) 3-14

Henderson, A. T. \& Mapp, K. L. (2002). A new wave of evidence: The impact of school, family, and community connections on student achievement. Austin, TX: Southwest Educational Development Laboratory

Ho, S.-C. E., \& Willms, J. D. (1996). Effects of parental involvement on eight-grade achievement. Sociology of Education, 69, 126-141.

Lingard, B \& Christie, C (2003). Leading theory: Bourdieu and the field of educational leadership. An introduction and overview to this special issue. International Journal of Leadership in Education, 6 (4), 317-333

Lingard, B., Rawolle, S. \& Taylor, S, (2000). Globalising Policy Sociology in Education:Working with Bourdieu. Journal of Education Policy 20 (6), 764.

Navarro, Z. (2006). In Search of Cultural Intepretation of Power. IDS Bulletin 37(6), 11-22.

Preston, J, P. and Barnes, K.E.R. (2017) Successful leadership in rural schools: A review of the literature. The Rural Educator, 38(1), 6-15, 2017

Reay, D. (2004). Education and Cultural Capital: The Implications of Changing Trends in Education Policies. Cultural Trends 13(2), 73-86.

Swartz, D. (1997). Culture and Power. The Sociology of Pierre Bourdieu. Chicago: University of Chicago Press 
Thomson,P (1999). Reading the work of school administrators with the help of Bourdieu: getting a 'feel for the game' Australian Association for Research in Education and New Zealand Association for Research in Education Joint Conference. Melbourne. November 30th - December $2^{\text {nd }}$. http://www.aare.edu.au/data/publications/1999/tho99060.pdf

Thomson, P (2018). Educational Leadership and Pierre Bourdieu. London: Routledge

Wacquant, L. (2005) Habitus. In J. Becket \& Z. Milan. (Eds.), International Encyclopedia of Economic Sociology (pp...). London: Routledge

Webb, J., Tony, S., \& Geoff, D. (2002). Understanding Bourdieu. London: Sage Publications.

Wong, P-M (2011) The village school context and principalship in Hong Kong: what do they contribute to leadership studies? School Leadership \& Management, 31:5, 517-543 